\title{
"You're My First Jew:" University Student and Professor Experiences of Judaism in a Small Indiana City
}

\author{
Emma Cieslik $^{1}$ (D) $\cdot$ Robert Phillips $^{1}$ (D)
}

Received: 11 September 2020 / Accepted: 13 July 2021 / Published online: 4 August 2021

(C) The Author(s), under exclusive licence to Springer Nature B.V. 2021

\begin{abstract}
There has been a Jewish presence in Muncie, Indiana since before the city was incorporated in 1865 . Most people, however, do not even know that the city has a synagogue or where it is located. This study contextualizes this small Jewish community within small-town America. For this study, we interviewed 12 Jewish individuals, including college students and faculty members at Ball State University, about their Jewish religion, identity, and experiences with antisemitism in this East-Central Indiana community. The interviews were transcribed and hand-coded for elements of Jewish life and identity, including the frequency of terms related to Jewish holidays, Christian dominance, and antisemitic interactions. These transcripts were also used to create a word corpus that was analyzed using a text analysis tool that calculates the frequency of dominant terms and their context. From this analysis, we determined that many Jewish college students and professors in Muncie experience Christian hegemony, not only because of public religious celebrations, feelings of difference, and Christian evangelization on campus and in public spaces, but also because many of the people interviewed revealed experiences of being someone's "first Jew," or the first Jewish person they have met.
\end{abstract}

Keywords Jewish studies $\cdot$ Jewish identity $\cdot$ Antisemitism $\cdot$ Small Jewish communities · United States

\section{Introduction}

Jews have lived in Muncie before the city was incorporated in 1865. Muncie is a small-to-medium-sized city with an estimated population of about 68,500 , situated in East-Central Indiana. It is best known for its role as "Middletown" in sociologists Robert and Helen Lynd's 1929 and 1937 studies of small-town America. Despite the long history of Judaism in Muncie starting with German and Central European

Emma Cieslik

eocieslik@gmail.com

1 Department of Anthropology, Ball State University, Muncie, IN 47306, USA 
Jews settling in rural areas in the mid- to late-nineteenth century, the Lynds found Muncie "a city of whose total population of Negros and foreign-born form only an infinitesimal part" and did not mention Jewish individuals in their first book. While the Lynds failed to comment on a group critical to Muncie's economic growth in the early twentieth century, more recently, researchers like Daniel Rottenburg have worked to fill this void through archival and oral history research (Rottenburg 1997).

In the early years, the Jewish population in Muncie worked hard to establish their religious community, fighting antisemitic backlash from political leaders and a dominant $\mathrm{Ku}$ Klux Klan. Despite these difficulties, the first Jewish services were held in members' homes before shifting to the Delaware Masonic Lodge No. 46 in 1891 and later to the Hebrew Temple from 1891 to 1896. The congregation then formed Temple Beth El in 1912, and in 1922 moved into what is Muncie's current and only synagogue. Temple Beth El is affiliated with the Reform Movement, and Jewish individuals wanting to attend Conservative or Orthodox services drive to synagogues in Indianapolis, which is approximately 50 miles away. Due to its consistently small number of members, Temple Beth El has relied on student rabbis from Hebrew Union College in Cincinnati, Ohio to lead services. Currently, Temple Beth El maintains an active sisterhood and regularly collaborates with the Hillel at Ball State.

As noted above, the Jewish community of Muncie has always been small, with between 25 and 35 member families, beginning with the arrival of Jewish settlers in the late nineteenth and early twentieth centuries. Jewish settlers faced similar difficulties to larger immigrant communities, including keeping their culture and religion alive between generations and resisting assimilation. Small town communities were unique in that they were more economically monolithic, consisting mostly of middle-class Jews working as merchants or entrepreneurs in business and junk collecting (Weissbach 2008). Despite, or perhaps because of, this success, in the early twentieth century they faced religious and race-based hatred from the $\mathrm{Ku}$ Klux Klan and from the broader culture in the form of exclusionary housing covenants and job discrimination.

Few anthropological studies have focused on Jews in small communities in the Midwest, and currently none exist for small towns in Indiana. Most scholarship related to Muncie's Jewish population has focused on recording the stories, customs, and ways of life of Jews in Muncie, a type of salvage ethnography. Writing centered on Muncie's Jewish community includes the Middletown Jewish Oral History Project I and II (1978-1979 and 2003-2004). This study hopes to fill this gap in scholarship by investigating the following questions.

1. How do Jewish students and professors experience their Jewish identity in a city with limited Jewish resources, including religious, cultural, and social resources?

2. How does being Jewish in small-town Indiana affect Jewish identity in light of increasing incidences of antisemitism?

To answer these questions, the authors focused on the experiences of students and professors attending or affiliated with Ball State University in Muncie. This 
is due to the fact that most of the current Jewish population in Muncie reside where they do because of attendance or employment at the University. Research has focused on collective identity among Jewish college students in the USA from the 1960s onward (Jospe 1964; Ruttenberg et al. 1996), but most research centers on universities in larger cities. Compared with Ball State, universities in larger Indiana cities offer more religious and cultural resources to Jewish college students, including, for example, through Hillel chapters. Ball State does have a Hillel chapter, but unlike regional Butler University and Indiana University's Hillel chapters, Ball State does not have a rabbi or full-time Jewish educator on campus. Purdue University and Indiana University offer weekly Shabbat services and kosher meals. Ball State's Hillel coordinates one to three Shabbat dinners at Temple Beth El per semester, and Temple Beth El hosts Shabbat services every other week, to which the Hillel students are invited.

\section{Literature Review: Jewish identity, Assimilation, Christian Privilege}

This study sits at the intersection of previous work that examines Jewish identity, assimilation, and Christian hegemony. Many different factors affect Jewish identity in small cities, including the smaller size of Jewish communities, limited religious resources, and assimilation of Jewish residents into the broader mainstream community. Judaism is more than simply a faith tradition in that it extends well beyond religious practice and identity. For many Jews, their religious identity includes connections to Israel, notions of racial belonging, and shared diet, and these factors that affect identity often vary from location to location. This is especially true of a small city like Muncie. As such, this paper works to understand local knowledge primarily using the participant's point of view (the emic perspective) collected through ethnographic interviews to study how living in Muncie affects the identification of Jewish residents.

Jewish identity is strongly linked to place. Jewish identity within the USA is not homogeneous but is affected by sociodemographic features of individual Jewish communities, according to a comprehensive study of 22 American Jewish communities conducted between 2000 and 2010 (Hartman et al. 2017). Unfortunately, Indiana was not included in this study. The sense of group belonging (family, synagogue, and community) is embedded in Jewish ritual (Chiswick and Chiswick 2000), and Jewish identity therefore involves institutional affiliation and Jewish group socialization and cohesion (Rebhun 2004). These "microcontexts," including friends, family, and schoolmates, greatly impact religiosity, shaping how important religion is in adolescents' and adults' lives (Regnerus et al. 2004).

Heilman (2003) encourages the right amount of pull between Jewish communities and their traditions and events that differ from tradition and events popularized in larger American society, as absorbing influences from the wider society stimulates individuals to oppose, insulate, mask, and reinterpret events (Goldberg 1990). One example where this tension slackens is Chrismukkah, involving the union of Jewish and Christian tradition (Mehta 2018). Common in intermarried households, Chrismukkah demonstrates that, while decisions often revolve around belief, 
practical considerations dominate. One sense of belonging relates to intermarriage (Handlarski 2020) and how public discussion of interfaith decisions revolve around belief, but everyday issues will tackle questions of practice (Mehta 2018). We also focus on Judaism's clash with wider Christian iconography, particularly the public display of Christian holidays with Christmas trees, Easter eggs (and crosses), and Christian music in public schools and universities, where the authors were conducting the study.

Like the blending of tradition in interfaith families, one aspect of blending in small-town life is assimilation. As assimilation is a contested idea in many minority communities, the authors focus on the transformational aspects of the process, following the examples of Rogers Brubaker (Brubaker 2003). Isolation from mainstream white and Christian culture leads some Jews to deny their Jewish identity to "blend in" (Altman et al. 2010). At Ball State, Jews may try to "blend in" to remain safe from antisemitism on campus and to have better employment or involvement opportunities, especially as many student organizations on campus are Christianaffiliated at Ball State. Some interviewees mentioned doing this by adopting a new non-Jewish appearance (such as not wearing a kippah in public), behavior, or diet to avoid discrimination, especially in Jewish communities that are not visible, like that in Muncie (Amyot and Sigelman 1996). Assimilation or "blending in" may work to improve social circumstances by protecting Jews from antisemitism (Alba and Nee 2009). Assimilation can form two different types, where (1) nonpracticing Jews who identify as Jews no longer consider religion important in their lives or (2) where nonpracticing Jews stop thinking of themselves as Jewish, often common in smaller Jewish populations (Alper and Olson 2013). Nonpracticing Jews may identify as Jewish based on culture, ethnicity, or ancestry instead of religious identity or religious practice. Therefore, while King and Weiner (2007) note that antisemitism is usually tied to communities with large numbers of Jews, and Muncie's Jewish population was not the main target of the KKK owing to its small size, the Jewish community was still impacted by religious and race-based hatred contributing to discrimination and a hegemony of Christianity in public spaces.

A demographic study conducted by Sheskin (2017) of the Indianapolis Jewish community in 2017 is one of two studies focused on Indiana. An anthropological study was conducted by Levine (1986), who investigated assimilation and integration among Jewish adults in Indianapolis. The Indianapolis Jewish population, consisting of 17,900 people with $50 \%$ of Jewish households living in the Indianapolis area for 20 years or more, is considerably larger than the Muncie Jewish population, which has remained in the triple digits since its inception, but it offers the only comparison available as it is the first study of any Jewish community in Indiana ever archived at the Berman Jewish Databank (Sheskin 2017). A few months before the Pew Research Center released their 2013 national study of the US Jewish population, Sheskin (2013) argued that researchers' best resource is to make use of these local Jewish community studies. One community study in the early twentieth century focused on the Jewish community in Indianapolis (Auerbach 1933). Even when there is no recent national study, local population studies do increase our understanding of the American Jewish population (Saxe and Tighe 2013) and may even be useful in ways that national studies cannot. 
While people may be integrated into either the Jewish or American community, the more they assimilate into the American community, the weaker the Jewish community becomes (Levine 1986). Many Jews do not identify themselves publicly, but rather feel alienated from mainstream culture, and some have even internalized antisemitism (Schlosser 2006). Often, Jews do not feel welcomed into communities, and the lack of acceptance manifests as comments, "You're not like all the other Jews" or "I would never have guessed that you're Jewish" (Hecht and Faulkner 2000), very similar to questions about the fixity of race and ethnicity explored through full-bodied ethnographies of Jewish communities (Markowitz 2006). Markowitz's analysis focused on Jewishness as performativity between embodied actors. This study of Jewishness in Muncie involved individuals who all self-identified as white, but these moments are also experienced by Jews of color in the USA and beyond.

Notably, Jewish-identified people reported perceiving more discrimination than their assimilated counterparts (Friedlander et al. 2010). Although many studies show that non-Jews are more accepting towards Jews than other groups (Kressel 2016; Putnam and Campbell 2012), $42 \%$ of Jews say that there is a lot of discrimination against Jews in the USA and $81 \%$ perceive antisemitism as problematic in the USA (Pew 2013). While no data exist for Muncie, 14\% of respondents in a 2017 Indianapolis study indicated that they had personally experienced antisemitism in the past year, and of those $14 \%$, about one-third said they had perceived a good deal or moderate amount of antisemitism in Indianapolis. (Sheskin 2017).

Many American Jews experience feelings of marginalization, alienation, microaggressions, bias, and discrimination (Schlosser 2006). Therefore, the history of Jewish diaspora shows selective accommodation with the cultural, political, and everyday life of new "host societies," in this case, through incidents of antisemitism in small-town America (Clifford 1994). While Diner (2004) discovered that reports of antisemitism are fewer among first- and second-generation Americans, studies focused on college populations show antisemitism reports are correlated with Jewish engagement (Kosmin and Keysar 2015; Saxe et al. 2009). Past studies have shown that group identification and membership is correlated with experiences of antisemitism (Tajfel and Turner 1986; Turner 1991). Other factors tied to antisemitic experiences include lower age, less education, American nativity, and attachment to Israel (Rebhun 2014). Among Jewish individuals identifying as Orthodox, religiously or ethnically Jewish belonging to a Jewish organization, or religiously or ethnically Jewish and not belonging to an organization, all perceived the presence of antisemitism (DellaPergola et al. 2009).

Past research connects religious oppression and antisemitic acts together, as Blumenfeld (2006) argues that oppression of non-Christians produces Christian privilege in the USA, and conversely, Christian privilege continually reinforces oppression of non-Christian people and faith communities. This incorporates the third area of literature, the hegemony of Christianity. Building on Young's (1990) five categories involved in oppression and privilege, including powerlessness, exploitation, marginalization, cultural imperialism, and violence, Blumenfeld (2006) argues that oppression also involves systemic constraints imposed upon groups that do not necessarily implicate violence, such as elements of tokenism and microaggressions. Past research has highlighted the promotion of Christianity in public schooling 
systems (Blumenfeld 2006). Clark and colleagues (2002) build on critical work studying manifested white privilege in the USA (McIntosh 1988) to identify Christian privilege regardless of how that identity is expressed. While protestants often hold most of this privilege (Blumenfeld 2006), it is the opposition of sameness and difference that parallels Protestant ship and other minority religious traditions that perpetuate the idea that Protestantism is the norm and that is acceptable for Christian expressions to persist in secular schools and other settings (Schlosser 2003), as highlighted in public spaces in Muncie and on Ball State's campus.

Lastly, this study employs the notion of bricolage, an idea first introduced by Claude Lévi-Strauss in his book The Savage Mind (1962) referring to how, in mythology, people combine available content to create something new. Riis and Woodhead (2010) further this theory to refer to the development of an individual religious framework, which Illman (2017) notes is driven by the consumerization of religious constructions where religious individuals can select different religious ideas to create their own worldview. Specific to our study, Altglas (2014) contradicts the focus on individual, independent constructions, explaining how economic, social, and political factors in the environment affect this available content, returning to Lévi-Strauss's original idea. The availability of Jewish religious resources, the absence of public Jewish imagery, and the dominance of Christian evangelization therefore strongly impact the environment in which Jewish identity is constructed, which is the focus of how Jewish individuals in Muncie construct their identity.

\section{Methods: Coding and Corpus Analysis}

For this study, the authors interviewed 12 Jewish individuals living in Muncie, Indiana. Of these, six were college students and five were professors or staff in different colleges at Ball State University. Undergraduate and graduate students were interviewed. The twelfth interview was with a local Jewish religious leader in Muncie who worked closely with university students. We began by reaching out to individuals from Muncie's only synagogue Temple Beth El as well as Ball State's Hillel chapter, a strategy often employed in ethnographies on Jewish identity construction (Feldman 2004). The interviews ranged between 30 and $60 \mathrm{~min}$, which were recorded and transcribed. They covered Jewish family relationships, Jewish identity in the context of Muncie, incidents of physical or emotional threats, Jewish jokes and harassment, and modern political leadership. All the interviews were handcoded, and a code book was constructed that included 34 unique codes falling into five main categories: Jewish identity, antisemitism, dominance of Christianity, the Jewish community in Muncie, and the greater Jewish community (see "Appendix" A).

A primary method of analysis employed in this study is corpus linguistics, in which any number of "everyday" texts are compiled into an electronic, machinereadable format (the corpus) and analyzed to expose previously unseen patterns related to grammatical or lexical features of the corpus. This is usually accomplished by comparing the corpus under investigation (the focus corpus) with a corpus of text that is representative of a given language (the reference corpus), 
allowing for a comparison of the patterns between corpora. Underlying this methodology is Renouf and Sinclair's notion (1991) that individual words do not carry meaning in themselves, but rather through their analysis as part of a larger sequence of words. In this study, we use Sketch Engine (Anthony 2013; Kilgarriff 2004, 2014), a widely available software package. Another feature of the method is that it involves a quantitative analysis of the data followed by qualitative interpretation. This is significant in that knowledge of a particular culture or issue is necessary for the researcher to properly unravel and interpret the patterns that emerge. For this study, this corpus linguistics is especially relevant in that it focuses the attention on the "real world" speech patterns of Jewish individuals from various segments of society from which attitudes and patterns can be extrapolated.

Analyzing this word corpus through corpus linguistics allowed the authors to conduct concordance and word sketch analysis related to the content of the interviews, including the frequency and connection between certain terms. This analysis yielded pie diagrams for specific terms, including "Jewish," "identity," Christian," and joke," which show the connection of these terms to others in the interview and the frequency of associated terms. The charts are discussed in the results section below. Corpus analysis offers a quantitative method of analyzing qualitative data, in this case the interviews conducted with 12 Jewish individuals.

\section{Results}

While the interviews encompassed a wide range of experiences, certain themes became prominent throughout, including (a) the small size of the Jewish community, (b) the prominence of secular Judaism, (c) the dominance of Christianity, (d) cautiousness in sharing Jewish identity, and (e) Jewish stereotypes and meeting their "first Jew." To protect the confidentiality of all interviewees, the names and identifying information for all interviewees were removed.

\section{Small Jewish Community}

While $72 \%$ of adults in Indiana are Christian, only $2 \%$ of adults in Indiana identify with another faith and $26 \%$ are unaffiliated. One percent of all religious adults in Indiana are Jewish (Pew Research Center 2014).

This Jewish community in Muncie has existed at Temple Beth El for over a century, and members have always dealt with the reality of being a small community. The people interviewed consistently emphasized that they live in a city with little Jewish representation and with a Jewish community that is shrinking or disappearing. Joshua spoke to this:

I feel that we are disappearing here, and I just wish that we were more than just those 20-25 families. 
Although the Jewish community in Muncie is small, Temple Beth El works not only to hold religious services but to avoid feelings of separation. Those who were interviewed frequently associated the words "community," "population," and "people" with the word "Jewish," as indicated by analysis of the word corpus (Fig. 1). For some who attend Temple Beth El, their desire to uphold Jewish religious practices comes from within and not from the synagogue or from the city. Diana spoke to this idea:

Keeping the High Holidays, or keeping any holidays, is up to me, not my community, or to my city.

In many ways, Diana's sense of personal responsibility for celebrating the High Holidays may stem from a lack of Jewish religious resources in Muncie. However, in many respects, Judaism can be considered a "religion of the home," and therefore, attendance at a synagogue is not mandatory. The city of Muncie has no kosher butchers or restaurants; although, most grocery stores in Muncie contain commercial food items that are kosher. Several people interviewed,

Jewish as adjective $358 \mathrm{x}-\quad$ Sorted by frequency $x \quad \ldots \quad$ \&

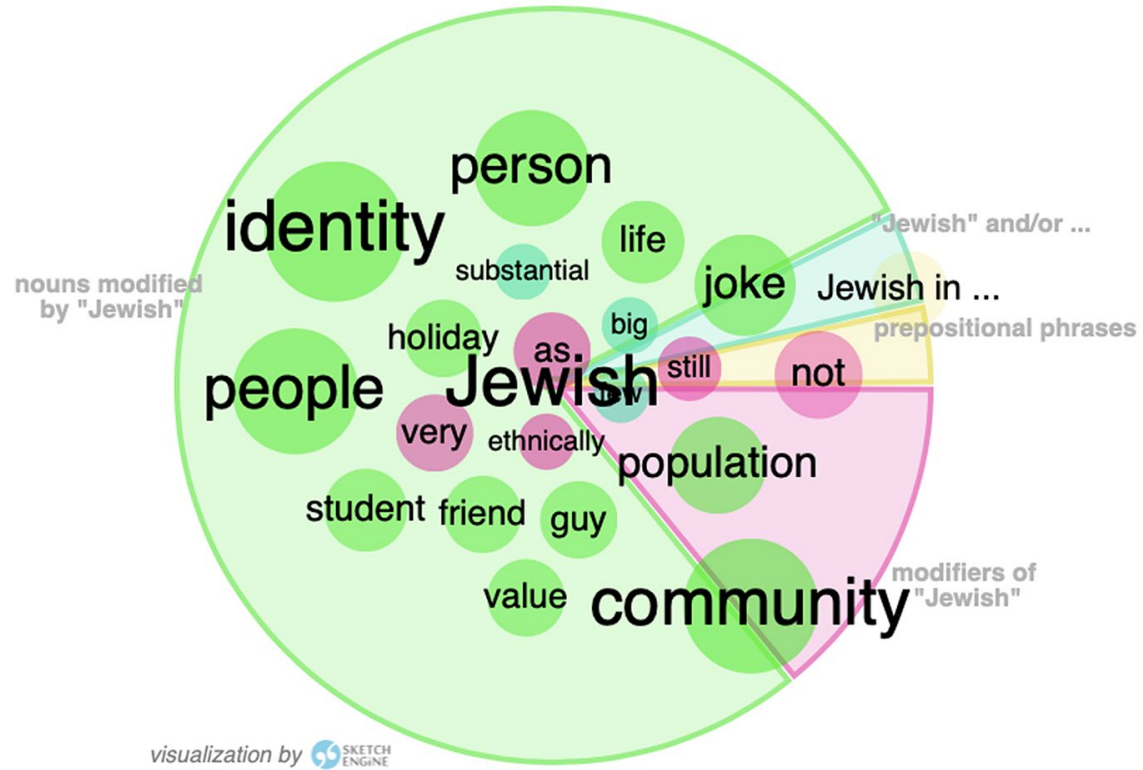

Fig. 1 Word sketch analysis for the word "Jewish," utilizing the word corpus of 12 interviews analyzed with Sketch Engine. The frequency of other words associated with Judaism in the interviews is indicated by the size of each bubble and separated based on type of word. The words "identity," "people," and "person" are closely associated with "Jewish," noting how Judaism is a significant part of the identities of those interviewed 
however, do drive to Indianapolis or Chicago to purchase kosher meat or order food online for upcoming holidays. Daniel spoke to how it is harder to be observantly Jewish in Muncie:

Being a Jewish minority in a place like Muncie, Indiana or like Cincinnati, Ohio, it's much harder to be observant; whereas, in Israel, everything is there for you, so you can decide if you are observing or not observing, but the community surrounds you and makes it easier.

Cincinnati has a much larger Jewish community, including Orthodox, Conservative, and Reform synagogues and a rabbinical school, and more Jewish resources, but in Muncie, there is no Jewish religious infrastructure outside of Temple Beth El, and for some this has led many to worry that they may not find support systems, and as Sam explains, this can lead him to think that his religious identity is being overshadowed or "minimized."

It has been challenging because I'm looking for support, and I don't always know if I am going to find it, and as a religious community, I just think that my beliefs are being minimized.

This experience of feeling "minimized" ties closely to prominent Christian displays and evangelization, discussed below. Others who were interviewed, often professors moving to Muncie in middle-to-late adulthood, see this void of Jewish representation and the fact that they live in a small Jewish community to necessitate involvement in the community. George notes:

Maybe if there is a big population, I wouldn't care but here they kind of need everyone, so, I have some obligation.

The idea of obligation paralleled a sense of community; Steven noted that community events help to decrease feelings of isolation:

It's important to have those few, at least, come together at some point, so we're not isolated and so we don't lose our way.

The people interviewed consistently note how Muncie has a small and shrinking Jewish community, but among those who are Jewish, there is a feeling of obligation to become more involved in the Jewish religious community because there are fewer people in Muncie to take on those roles. Feelings of isolation and fears for openly identifying as Jewish likely stem from Christian religious dominance in Muncie, especially evangelism efforts targeted at students on Ball State University's campus. Also, most Jewish individuals enter the community as a student or faculty member at Ball State, so students may not be expected to stay in the community for more than 4 years, which may impact their involvement with the community. 


\section{Prominence of Secular Judaism}

Jewish identity extends beyond religious practice, which is different from other dominant religious practices in the USA, including Christianity. Recent studies have shown a rise in Jewish secularism among college students (Kosmin 2018) largely impacted by upbringing and intermarriage (Keysar 2018); this fact was mirrored in our interviews. Word sketch analysis indicates that those interviewed closely associate identity with the term "Jewish," but they do so in a way that can allude to an "ethnic," "cultural," or "national" identity separate from religious identity (Figs. 1 and 2). Several people interviewed, specifically students, note how their Jewish identity is not tied to religious practices or dietary observances. The term "nonobservant" is often used interchangeably with "secular," but those interviewed did

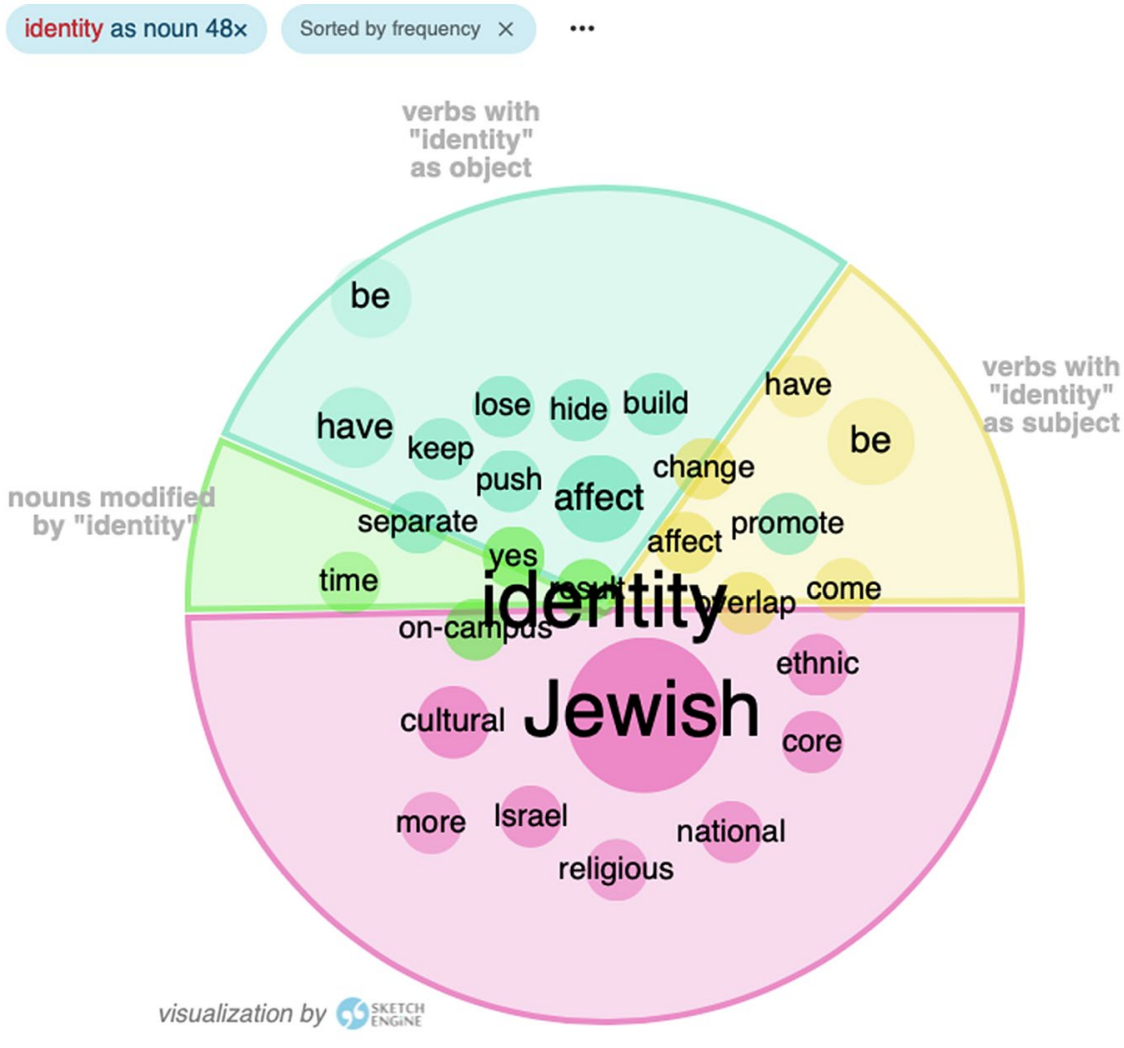

\section{modifiers of \\ "identity"}

Fig. 2 Word sketch analysis for the word "identity," utilizing the word corpus of 12 interviews analyzed with Sketch Engine. "Jewish" is closely related to "identity," but terms like "ethnic," "cultural" and national" allude to a Jewish identity that extends beyond religious tradition related to growing secularism among Jewish young people 
not indicate loss of Jewish identity when not attending services but rather self-identification based on ancestry, ethnicity, and social community. Isabella explained her own identity:

That's kind of what's cool about Judaism is that you can never practice a single custom, never keep kosher or anything like that associated with being Jewish, but you can still be considered just as Jewish as anyone else.

The people interviewed who identify as Jewish "by birth," also referred to themselves as "secular." Smith and Zhang found that, among a Jewish community in a city in the southern USA, ancestry plays an increasing role in Jewish identity, as most consider it inherited or inherited as well as chosen and constructed (Smith and Zhang 2018). The 2013 Pew study also found that almost $25 \%$ of Jewish adults in the USA identify as Jewish by some other factor besides religion (Pew Research Center 2013). They may or may not attend Temple Beth El, and even if they do, they may be doing so for social reasons rather than religious ones. Lucy spoke to why many people attend Temple Beth El,

Probably the majority of the Jewish community in Muncie is involved with the temple on a social setting rather than a religious setting.

As mentioned above by Steven, events that bring together the Jewish community work to fight feelings of isolation, so social events are a critical piece in developing a support system. The young people interviewed who did not identify as religiously mainly came from households with one Jewish parent and one non-Jewish (often Christian-identified) parent and were from the Midwest. The Jewish parent was often the mother. While studies have shown that there is decreased religiosity among Jews raised in the Midwest by interfaith parents (Smith and Young 2018), recent studies of college students and intermarried couples show that children born of intermarriage often experience faith like children with two Jewish parents when they are incorporated into Jewish communities (Saxe et al. 2009; McGinity 2012; Thompson 2013). Those interviewed do attend Temple Beth El for social reasons and closely associate Judaism with family social events. Shawn explained:

A lot of the value that I find in Judaism and all that kind of stuff really is more of a familial get-together and stuff like that.

While "secular" identity was mainly confined to the younger people who were interviewed, several other people characterized themselves as "ethnically" Jewish. For Dominick, how he identified as Jewish depended on his surroundings:

In Israel, I saw myself as secular. I do think of myself as secular, but I would say maybe ethnically Jewish more than observant.

For one interviewee, Israel played a key role in the identity construction process. He previously identified as secular or nonreligious while in Israel, but when outside of a Jewish state, his Jewish identity was closely tied to his ethnic identity, and he 
became involved in the Temple community. This experience reflects only one person and merits future research. The Word Sketch analysis confirms the varied types of Jewish identities, noted with the use of the words "ethnic," "national," and "cultural" alongside the word "religious" discussing identity (Fig. 2). This is likely a result of growing secularism among Jewish young people from intermarried parents and ethnic and cultural identities tied to national ties and identities, including to Israel.

\section{Predominance of Christianity}

Religious, as well as cultural and ethnic identity as mentioned above, can be manifested publicly and privately, and this theme focused on how Jewish identity was represented in Muncie. When asked about Jewish representation in Muncie, many of the people interviewed noted how Christian symbols and iconography dominated public spaces, including decorations for Christmas and Easter. Word Sketch analysis revealed that those interviewed used the words "be" and "very" as well as "holiday" closely associated with "Christian," showing how predominance of Christian symbols often mirrors evangelization efforts by Christian organizations on campus (Fig. 3). On Ball State University's campus, the prominence of Christmas trees, songs, and events overshadows what little, if any, Jewish decorations exist. Visibility and recognizing a visual culture are central to identity formation (Zemel 2015). One Ball State student, Veronica, spoke to the lack of Hanukkah decorations:

If you are going through Ball State and it's the time of year, like December, count how many Hanukkah decorations that you see. This is my sixth year on campus, and it has not gotten better. It's all Christmas lights, wreaths and trees and presents, and they're playing holiday music on the speakers in the buses. No menorah. Not a single menorah.

Other Ball State students who were interviewed recalled how Muncie community members passed out New Testament Bibles at the main thoroughfare of campus. This area also played host to other Ball State Christian student organizations, including Cru and Awaken, largely focused on evangelization. Larry, another student, explained:

I think there is definitely a lack of representation, and I guess you can see that with the dominance of $\mathrm{Cru}$, so when you have the bigger organizations that have the dominance, then with the smaller organizations [like Hillel], it's harder for them to be known and get more involved.

Ball State does have a Hillel chapter, but membership is consistently small, with five to ten students attending most meetings. In fall 2019, the organization partnered with an older member of Temple Beth El to organize Hebrew lessons for students, but attendance at these events remained in the single digits until they were discontinued due to coronavirus. Although Hillel provides a space for social gatherings, Jewish college students still receive fliers for Christian organizations and churches in their dorm mail. 


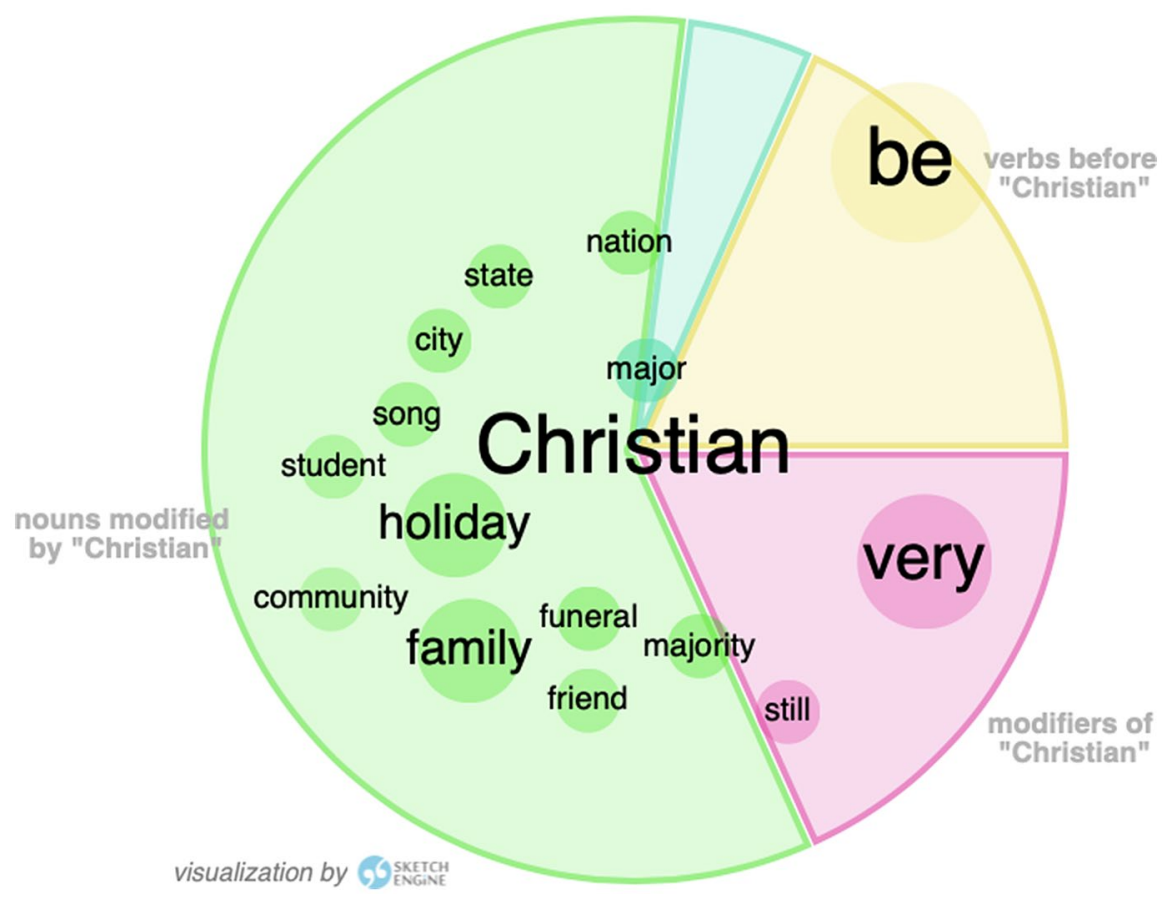

Fig. 3 Word sketch analysis for the word "Christian," utilizing the word corpus of 12 interviews analyzed with Sketch Engine. The words "be" and "very" appeared frequently when the people interviewed were asked about Christianity. Other terms include "holiday," alluding to the dominance of Christian holidays, and "family," referring to Jewish young people from interfaith homes that celebrate Christian holidays

Beyond Ball State students, elementary and middle schools in Muncie are largely Christian-oriented. For Jewish professors working to raise their children Jewish in Muncie, they are working against a school year with Christian holidays "built into the school breaks" and schools celebrating Christian holidays in the classroom. Susan, a Ball State professor explained:

It's a hard role because I have to constantly remind my kids that Christmas is a great holiday. It's wonderful, but it's not our holiday.

Mark, another parent, noted how his daughter was the only Jewish student he knew of in her school, making it difficult to seek out other parents for guidance. Lucas explained how, in Muncie, "Judaism is almost a non-entity here," as if it does not exist. Some people the authors spoke to at Ball State and in Muncie did not know that it had a synagogue. A former student rabbi explained her initial reactions when arriving at Temple Beth El:

Even if you look at the synagogue building, the first time that I came here, I drove right past it because I couldn't see that this was a synagogue. It wasn't 
really clear from the outside, which is very common in synagogues in many places in the world where they try to blend in and not stick out too much and not show they are Jewish externally so much. I think just because of the numbers. It is such a small community. It's not a public presence as much in Muncie.

This rabbi's note about Temple Beth El parallels another theme in the interviews, a cautiousness to share Jewish identity, linked partly to increasing antisemitism in the USA.

\section{Cautiousness in Sharing Jewish Identity}

While Muncie's Jewish community is small, its community members still perceive the risks of antisemitism and bigotry witnessed in larger Jewish communities. Several people interviewed mentioned that they felt physically unsafe when attending Temple Beth El, even though a police officer is on-duty during all services as well as other events held at the temple. Rachel commented that "my personal safety is at risk," whereas Diana remarked that her risk is always on her mind when attending temple services:

Yes, every time that I go to the synagogue it crosses my mind.

When asked if this risk would compel them to give up their Jewish identity, the majority of those interviewed said no but noted that they are less likely to talk about their Jewish identity in public, wear symbols of Judaism (including a kippah or Magen David jewelry), and are generally "more cautious" because of modern examples of antisemitism-motivated violence. This fear is therefore affecting their physical embodiment of their identity and mirrors an absence of Jewish cultural and religious symbols in public spaces in the Muncie community.

The authors conducted these interviews between September and December 2019, one year after the Pittsburgh synagogue shooting at the Tree of Life/Or L'Simcha Congregation, but this tragic event still affected the people interviewed. Stacey explained her fear:

After they had that shooting last year at the temple, I was calling my mom asking if I should wear my Jewish star necklace anymore.

Another man, Roger, noted how he has taken off his kippah or put his hood up to hide that he is wearing it to stay safe. Parents interviewed explained how fear associated with this recent antisemitic attack, along with other occurring in Hasidic communities in New York City in December 2019, makes it difficult to instill feelings of pride in their children: 
We try to teach our kids to be proud of who they are, while at the same time, we try to teach them a modicum of not necessarily going and flaunting it because we're concerned that drawing attention to you, in that way, could have adverse effects.

Even several of the young college students describe growing up with family members that explicitly said to "never advertise your religion" or to limit expression of Jewish identity to stay safe. In a city where the small Jewish community bands together for social and religious events to work against feelings of isolation, the Jewish community also feels cautious to express this identity openly, especially when the city has explicitly Christian events and symbols.

\section{Jewish Stereotypes and the "First Jew"}

Just as few people living in Muncie, Indiana know that their city has a Reform synagogue, many people in Muncie, Indiana have never met a Jewish person. Several people interviewed explained how, when people find out that they are Jewish or when they share their Jewish identity, that person admits that they have never met anyone who is Jewish, that this person is their "first Jew." Sarah explained her own experience:

I guess a lot of people who come here to Ball State, maybe they're from a smaller town in Indiana or maybe they're from Muncie, but they don't know a lot of Jewish people. It's very, very common to me, when people find that I am Jewish, they have never met a Jewish person before.

While Sarah explained that she sees her Jewish identity "as a diamond in the rough for more people to know about it," she also discusses how being this person's "First Jew" can be tiring, always being placed in a minority that the often-Christian majority have not encountered and do not understand. Henry remarked how people often assume that he is Christian:

Whenever I say that I am Jewish, it's always the funniest thing because people are always so surprised that I am not Christian.

For those in Muncie that do not know what Judaism is, this can lead to confusion, harmful statements, and inappropriate jokes. One woman interviewed noted that her boyfriend's family did not know what Judaism was, and while they affirmed that it was okay that she was Jewish, they still thought that she believed in the divinity of Jesus Christ. This confusion and misunderstanding can lead to antisemitism, here exemplified by the prominence of Jewish jokes.

This lack of experience speaking with Jewish people has led to misunderstandings about what Judaism is and has perpetuated stereotypes about Jews manifested as Jewish jokes and, more insidiously, Holocaust jokes. Several people interviewed note that many people they encounter in Muncie do not know how to speak with or interact with 
a Jewish person, leading them to tell Jewish jokes, thinking it will not bother this person or not even realizing that this person is Jewish. Stacey explained how "harmless" jokes can turn dark:

I find that often time when people do get really cruel is when they are just having fun because then they try to turn it into, "I was just joking around. I'm not being serious." But they are.

Several other people interviewed, mostly young people remark how they feel they "had to laugh it off" or turn the other way when people used phrases like "Jew it down," to refer to getting the price reduced. Word Sketch analysis of the interviews indicate that, when discussing "Jewish" identity, most interviewers used the term "Jewish" in close association with "joke," "stereotypical," and "Holocaust" (Fig. 4). While some are hopeful that awareness about the derogatory phrase will help it to stop being used, others worry that an explanation is not enough for people to stop using these phrases. Walter explained hearing people's use of "Jew it down":

He had not a clue that I was Jewish. That was his term for it, and talking to the guy, I don't think any amount of explanation as to how that is not acceptable would have made him understand.

The use of this phrase and other terms are harmful to the Jewish community and survive on stereotypes related to physical appearance and greed. When people are no longer able to accept the reality of these phrases, terms, or jokes as unacceptable, jokes about genocide, about the Holocaust, are seen as acceptable and "not serious," even though all of these terms, phrases, and jokes allude to underlying antisemitism and, worse, socially permitted antisemitism. One person interviewed noted how they felt threatened because "there has been a rise in overt antisemitism."

While the authors were conducting the interviews, a group put up posters across Ball State's campus on the day before Rosh Hashanah (29 and 30 September 2019) warning that a Neo-Nazi group would be coming to campus. While the posters encouraged students to oppose the group, the Ball State students that the authors interviewed after the incident argued that it seemed more like a group declaration (Fig. 5). When one young Ball State student showed a picture of the posters to the University Police Department, she had to explain the threat to Temple Beth El members like herself because the flyers promoted the group coming to campus right during the High Holidays. This experience highlighted ignorance about the existence of a Jewish community in Muncie and an understanding of Judaism and when important Jewish holidays occur, critical to protecting all members of the community. 
joke as noun $49 \times>\quad$ Sorted by frequency $x \quad$...

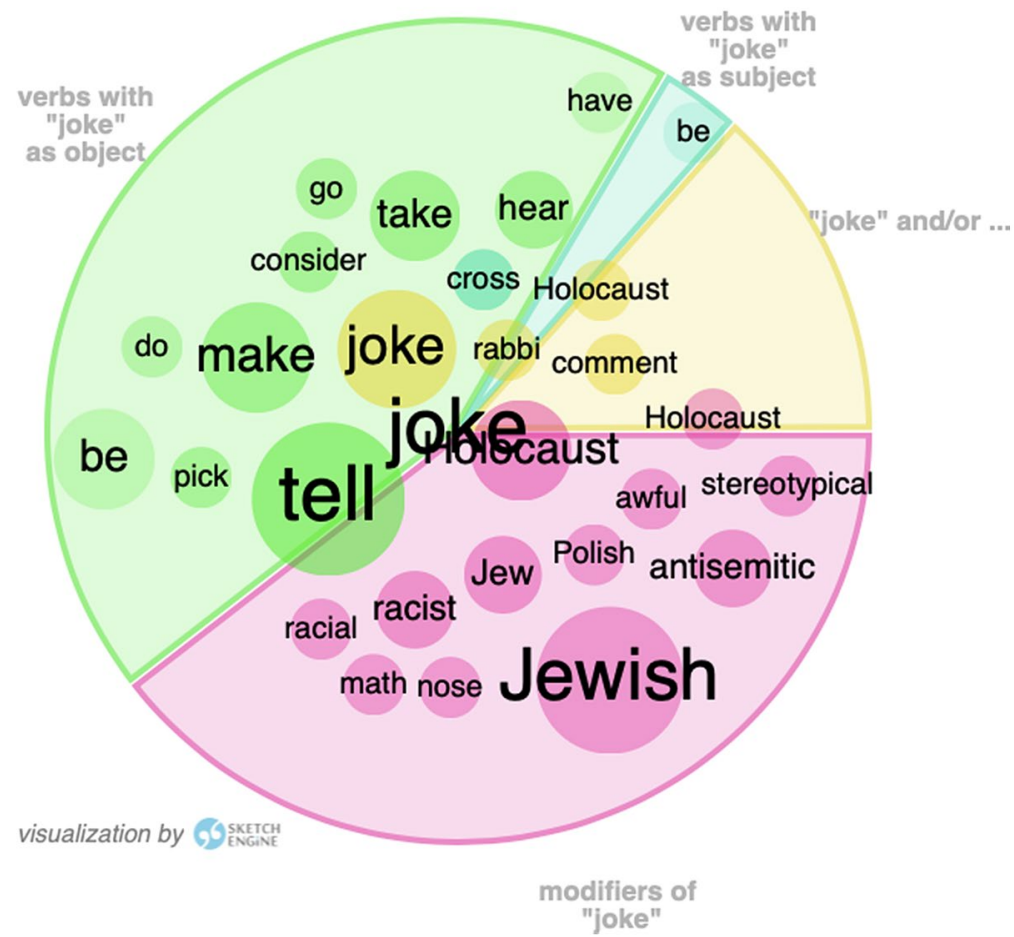

Fig. 4 Word sketch analysis for the word "joke," utilizing the word corpus of 12 interviews analyzed with Sketch Engine. The term "Jewish" is closely related to jokes, along with "Holocaust," "antisemitism," "stereotypical," and "racist," referring to Holocaust jokes and Jewish stereotyping. The prominence of the verbs "tell" and "make" refer to how the people interviewed have heard people tell these jokes, referring to the action, as opposed to receiving the jokes, with the lesser use of the word "hear." The association between "joke" and "be" also shows how Jewish people may believe others view Jewish identity as a joke

\section{Analysis}

The authors encountered a small but strong Jewish community in Muncie, Indiana committed to holding social and religious events despite the lack of resources. The interviews highlighted how Jewish identity varies based on life stage and environmental context (Cohen 1998; Alba 2006; Roehlhepartan et al. 2011), how the experiences of Jewish people in Muncie depend on their upbringing (single or interfaith household), surroundings (living in a Jewish nation versus the USA), and their past experiences with antisemitism. This research therefore supports how Jewish identity can vary based on secular and ethnic identity, regardless of the religious observance of the person interviewed (Friedman et al. 2005, Samson 


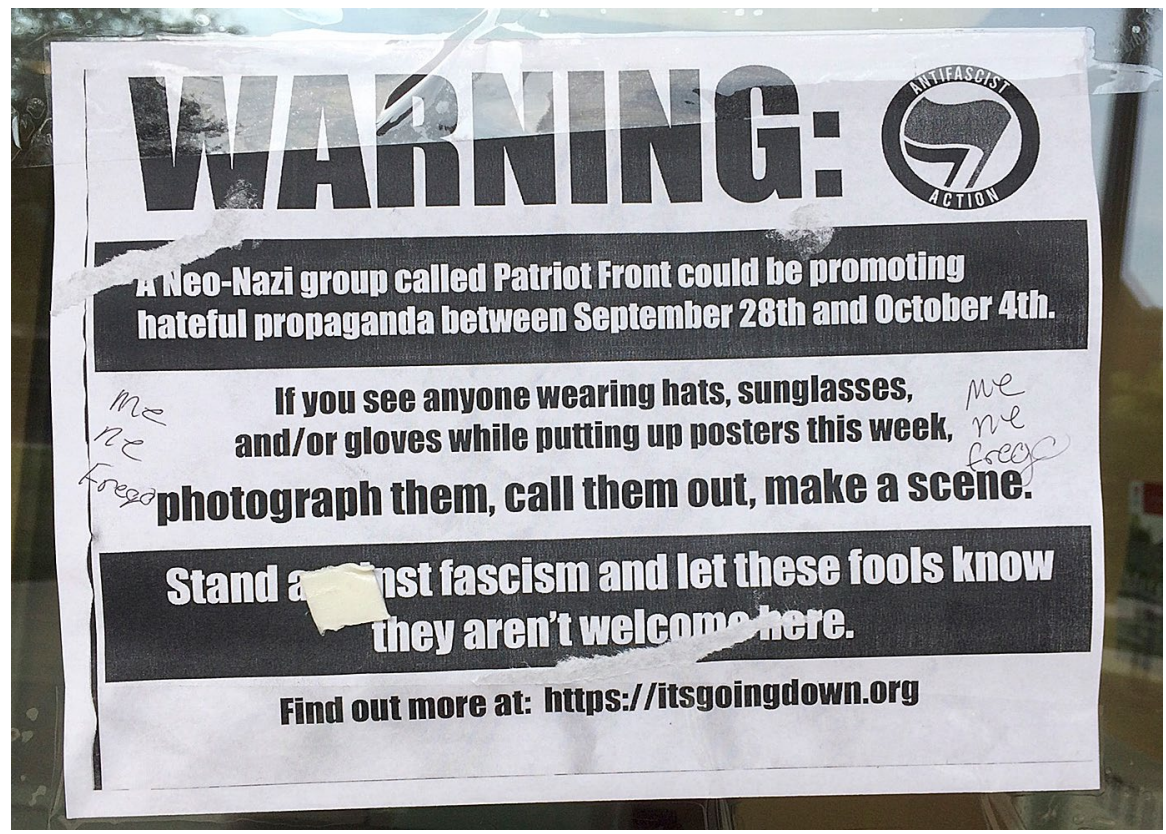

Fig. 5 Flyer promoting Neo-Nazi group coming to Ball State. These flyers were posted throughout campus in late September 2019, advising that a Neo-Nazi group called Patriot Front, would soon be coming to Ball State campus. It took several days for the posters to be taken down by the police. Most of them were torn down immediately by Ball State students. Patriot Front is a white nationalist hate group that separated from Vanguard America after the deadly Charlottesville rally in August 2017. Many of their rallies featured swastikas and other Nazi-era imagery and chanting, "Jews will not replace us" (Southern Poverty Law Center 2020)

et al. 2018). The majority of those interviewed indicated that they identified more with secular Judaism and so looked to Temple Beth El as a locus of ethnic and cultural community. The small size of the community necessitates that many take up leadership and membership roles for this religious and social resource to be available to Jewish members of the community.

While Ball State draws a wider variety of students from across the USA and the world, more religiously oriented Ball State students may choose universities with an established campus rabbi, large Hillel organization, and kosher resources, which Ball State does not offer. In the case of these students, access to Jewish resources may not predominate in their college decision or may revolve around maintaining a strong Jewish community or family in their hometown because there exists great variability among secular Jewish young people (Buckser 2011; Keysar 2010). Whether the authors encountered more secular Jews because the Jewish religious resources were not part of their college decision or because they came from the Midwest, where interfaith upbringings are common, would be an interesting topic for a future study of secular Judaism in small cities and college towns in the Midwest. 
Many people interviewed commented about not wearing Jewish clothing to protect themselves, and this trend parallels social stigma related to presenting Jewish in the corporate and academic world (Chiswick and Chiswick 2000). On a college campus where students encounter Christian evangelization and open warnings about Neo-Nazi groups (Fig. 5), the students who were interviewed avoid "presenting" their Jewish identity for fear that it could endanger their personal safety. According to the Anti-Defamation League, a significant number of incidents occurred at K-12 schools and on college campuses in 2018 ("Antisemitism in the US" 2020). Beyond this campus, Ball State students struggle to integrate into a Jewish community because there are no public Jewish symbols to attach to in Muncie. They often face dominant Christian symbols and evangelization. Despite these obstacles, including little visibility in the Muncie community and few resources, the Jewish community in Muncie, Temple Beth El, still stands, still practices, and still comes together to fight isolation.

For one Ball State student, representing Hanukkah in Muncie is her way to incorporate her Jewish identity into her everyday visual landscape despite the presence of Christian symbols and the acceptability of the Christian evangelization in school spaces. Abramitzsky and colleagues (2010) found that American Jews are more likely to celebrate Hanukkah if they live in areas with low Jewish market shares, working to counteract the influence of other religions (Abramistzky et al. 2010, Cohen-Zada and Elder 2018). Hanukkah is a minor holiday compared with the High Holidays in the fall, but many people closely associated Hanukkah as the Jewish equivalent of Christmas providing an easily explainable, yet incorrect, representation of Judaism to a largely Christian-dominated community in the American Midwest.

Bricolage, Lévi-Strauss' idea of putting existing ideas and things to new purposes, a type of cultural DIY if you will, seems an apt framing for this study in that individual religious constructions are the product of the environment in which religious traditions, services, and resources are available. Each person interviewed showcased how their religious identity is a pastiche of different traditions, including electronic menorahs, kosher food road trips, and Hillel meetings.

The Jewish population in Muncie, Indiana has remained a small but integral part of the economic and cultural landscape of Muncie for over a century, and today, during a time of increasingly overt antisemitism, the Jewish population at Ball State and Muncie has centered itself around the Temple Beth El community for social and religious events that counteract feelings of isolation and separation in a city dominated by Christian symbols. As there are few Jewish Ball State students and professors, it can lead to misunderstandings about what Judaism is. While the experience of being someone's "First Jew" can be rewarding in breaking down these stereotypes, it can be difficult and upsetting for Jewish individuals who may encounter Jewish jokes and stereotypes along the way. 


\section{Appendix A: Codebook: codes and subcodes}

1. Jewish identity

Family religious observance

One Jewish parent

Two Jewish parents

Proximity to immediate family

Keeping kosher

Wearing a kippah

\section{Antisemitism}

$\mathrm{Ku}$ Klux Klan

Holocaust

Differentness or otherness

Jewish or Holocaust-related jokes

Classroom setting

"First Jew"

Hiding Jewish identity

Not socially accepted

Persecuted

Hateful looks and comments

President Trump

3. Dominance of Christianity

Push of Christianity

Dominance of Christian

Student organizations

Christian Church

Christmas or Easter

Jesus Christ

4. Muncie Jewish community

Little Jewish representation

Small or shrinking community

Ball State Hillel

Lack of resources

Lack of support

Lack of understanding

Isolation

Jewish holidays

Temple Beth El

Give up Jewish identity 


\section{Refuse to give up Jewish identity}

\section{Worldwide Jewish community}

Israel.

Acknowledgements Thank you to the three anonymous reviewers of this manuscript for their edits and comments and to the editors and staff at Contemporary Jewry for seeing this project through.

\section{References}

Abramitzky, R., L. Einav, and O. Rigbi. 2010. Is Hanukkah responsive to Christmas? The Economic Journal 120 (545): 612-630.

Alba, R. 2006. On the sociological significance of the American Jewish experience: Boundary blurring, assimilation, and pluralism. Sociology of Religion 67 (4): 347-358.

Alba, R.D., and N. Victor. 2009. Assimilation and contemporary immigration. Harvard University Press.

Alper, B.A., and D.V.A. Olson. 2013. Religious population share and religious identity salience: Is Jewish identity more important to Jews in less Jewish areas? Sociology of Religion 74 (1): 82-106.

Altglas, V. 2014. 'Bricolage': Reclaiming a conceptual tool. Culture and Religion 15 (4): 474-493. https://doi.org/10.1080/14755610.2014.984235.

Altman, A.N., A.G. Inman, S.G. Fine, H.A. Ritter, and E.E. Howard. 2010. Exploration of Jewish ethnic identity. Journal of Counseling \& Development 88 (2): 163-173.

Amyot, R.P., and S. Lee. 1996 Jews without Judaism? Assimilation and Jewish identity in the United States. Social Science Quarterly 77 (1): 177-189.

Anthony, L. 2013. A critical look at software tools in corpus linguistics. Linguistic Research 30 (2): 141-161.

Antisemitism in the US. Anti-Defamation League Website. https://www.adl.org/what-we-do/anti-semit ism/anti-semitism-in-the-us. Accessed 20 January 2020.

Auerbach, Myra. A study of the Jewish settlement in Indianapolis. PhD diss., Indiana University, 1933

Blumenfeld, W.J. 2006. Christian privilege and the promotion of "secular" and not-so "secular" mainline Christianity in public schooling and in the larger society. Equity \& Excellence in Education 39 (3): 195-210.

Brubaker, Rogers. 2003. The return of assimilation? Changing perspectives on immigration and its sequels in France, Germany, and the United States. In Toward assimilation and citizenship: Immigrants in liberal nation-states, eds. Christian Joppke and Eva Morawska, 39-58. London: Palgrave Macmillan.

Buckser, A. 2011. Secularization, religiosity, and the anthropology of Jewry. Journal of Modern Jewish Studies 10 (2): 205-222.

Southern Poverty Law Center. Patriot front. Southern Poverty Law Center Website. 2020. https://www. splcenter.org/fighting-hate/extremist-files/group/patriot-front. Accessed 20 January 2020.

Chiswick, C.U., and B.R. Chiswick. 2000. The cost of living Jewishly and Jewish continuity. Contemporary Jewry 21 (1): 78.

Christine, C., M. Brimhall-Vargas, L. Schlosser, and C. Alimo. 2002. Diversity initiatives in higher education: It's not just "Secret Santa" in December: Addressing educational and workplace climate issues linked to Christian privilege. Multicultural Education 10 (2): 52.

Clifford, J. 1994. Diasporas. Cultural Anthropology 9 (3): 302-338.

Cohen, S.M. 1998. Religious stability and ethnic decline: Emerging patterns of Jewish identity in the United States. New York: Jewish Community Centers Association.

Cohen-Zada, Danny, and Todd Elder. 2018. Religious pluralism and the transmission of religious values through education. Journal of Economic Behavior \& Organization 150: 325-349.

DellaPergola, Sergio, Shlomit Levy, Uzi Rebhun, and Dalia Sagi. 2009. Patterns of Jewish identification in the United States, 2001. In Theory construction and multivariate analysis: Applications of facet approach, eds. Dov Elizur, and Eyal Yaniv. Ramat-Gan, Israel: FTA Publications. 
Diner, H.R. 2004. The Jews of the United States 1654 to 2000, vol. 4. Univ of California Press.

Feldman, Jeffrey D. 2004. The Jewish roots and routes of anthropology. Anthropological Quarterly 77(1): 107-125.

Friedlander, M.L., and V.G. Mikhaylov. 2010. Introducing a brief measure of cultural and religious identification in American Jewish identity. Journal of Counseling Psychology 57 (3): 345.

Friedman, M.L., M.L. Friedlander, and D.L. Blustein. 2005. Toward an Understanding of Jewish Identity: A Phenomenological Study. Journal of Counseling Psychology 52 (1): 77-83.

Goldberg, Albert I. 1990. American assimilation or Jewish revival? By Steven M. Cohen (book review). Social Forces 68 (4): 1352.

Handlarski, D. 2020. The A-Z of intermarriage. University of Toronto Press.

Hartman, H., I.M. Sheskin, and E.H. Cohen. 2017. Multi-dimensional analysis of Jewish identity in 22 American Jewish communities. International Journal of Religions and Traditions 2 (1): 19-31.

Hecht, Michael L., and Sandra L. Faulkner. 2000. Sometimes Jewish, sometimes not: The closeting of Jewish American identity. Communication Studies 51 (4): 372-387.

Heilman, S.C. 2003. American Jews and community: A spectrum of possibilities. Contemporary Jewry 24 (1): 51-69.

Illman, R. 2017. 'Retaining the tradition-but with an open mind': Change and choice in Jewish music practices. Temenos: Nordic Journal of Comparative Religion 53 (2): 207-229.

Jospe, Alfred. 1964. Jewish college students in the United States. The American Jewish year book 65: 131145. Accessed July 20, 2020. www.jstor.org/stable/23602980.

Keysar, A. 2010. Secular Americans and secular Jewish Americans: Similarities and differences. Contemporary Jewry 30 (1): 29-44.

Keysar, Ariela. 2018. The persistence of American Secular Judaism: Jewish millennials. In Jewish Population and Identity, eds. Sergio Della-Pergola and Uzi Rebhun, 85-97. Springer, Cham. https://doi.org/10. 1007/978-3-319-77446-6_5.

Kilgarriff, Adam, Pavel Rychly, Pavel Smrz, and David Tugwell. 2004. Itri-04-08 the sketch engine. Information Technology 105: 116.

Kilgarriff, Adam, Vít. Baisa, Jan Bušta, Miloš Jakubíček, Vojtěch Kovář, Jan Michelfeit, Pavel Rychlý, and Vít. Suchomel. 2014. The Sketch Engine: Ten years on. Lexicography 1 (1): 7-36.

King, Ryan D., and Melissa F. Weiner. 2007. Group position, collective threat, and American anti-Semitism. Social Problems 54 (1): 47-77.

Kosmin, Barry A., and Ariela Keysar. National demographic survey of American Jewish college students 2014: Anti-Semitism report. (2015).

Kosmin, Barry A. 2018. The Jewish secularization thesis and the revival of American Jewish Secularism: The case of college students in 2014. In Jewish Population and Identity, eds. Sergio DellaPergola and Uzi Rebhun, 73-83. Cham: Springer. https://doi.org/10.1007/978-3-319-77446-6_4.

Kressel, NJ. 2016. How to interpret American poll data on Jews, Israel and Antisemitism. In Antisemitism in North America: Old World, New Hate, eds Stephen K. Baum, Neil J. Kressel, Florette Cohen, Steven Leonard Jacobs, 1-32. Leiden: Brill.

Levine, Betty C. 1986. Religious commitment and integration into a Jewish community in the United States. Review of Religious Research 27 (4): 328-343.

Markowitz, Fran. 2006. Blood, soul, race, and suffering. Anthropology and Humanism 31 (1): 41-56.

McGinity, K.R. 2012. Still Jewish: A history of women and intermarriage in America. NY: NYU Press.

McIntosh, P. 1998. White privilege and male privilege: A personal account of coming to see correspondences through work in women's studies. Wellesley, MA: Wellesley College Center for Research on Women.

Mehta, S.K. 2015. Chrismukkah: Millennial multiculturalism. Religion and American Culture 25 (1): 82-109.

Mehta, S.K. 2018. Beyond Chrismukkah: The Christian-Jewish interfaith family in the United States. NY: UNC Press Books.

Pew Research Center. Religion and public life project: 2013 survey of US Jews and the 2013 American Jewish committee survey. Pew Research Center. (2013). Accessed 23 November 2019. https://www.pewfo rum.org/2013/10/01/jewish-american-beliefs-attitudes-culture-survey/.

Pew Research Center. Religious landscape study: Adults in Indiana. Pew Research Center Religion and Public Life (2014). Retrieved from https://www.pewforum.org/religious-landscape-study/state/indiana/.

Putnam, Robert D., and David E. Campbell. 2012. American grace: How religion divides and unites us. Simon and Schuster.

Rebhun, Uzi. 2014. Correlates of experiences and perceptions of anti-Semitism among Jews in the United States. Social Science Research 47: 44-60. 
Rebhun, Uzi. 2004. Jewish identity in America: Structural analyses of attitudes and behaviors. Review of Religious Research 46 (1): 43-63.

Regnerus, Mark D., Christian Smith, and Brad Smith. 2004. Social context in the development of adolescent religiosity. Applied Developmental Science 8 (1): 27-38.

Renouf, Antoinette, and John Sinclair. 1991. Collocational frameworks in English. English corpus linguistics. In English corpus linguistics, 128-143. Oxfordshire, England: Routledge.

Riis, O., and W. Linda. 2010. A sociology of religious emotion. Oxford: Oxford University Press.

Roehlkepartain, E.C., P.L. Benson, and P.C. Scales. 2011. Spiritual identity: Contextual perspectives. In Handbook of identity theory and research, ed. V.L. Vignoles, 545-562. New York: Springer.

Rottenberg, Daniel. 1997. Middletown Jews: The tenuous survival of an American Jewish community. Bloomington: Indiana University Press.

Ruttenberg, J., M.C. Zea, and C.K. Sigelman. 1996. Collective identity and intergroup prejudice among Jewish and Arab students in the United States. The Journal of Social Psychology 136 (2): 209-220. https:// doi.org/10.1080/00224545.1996.9713995.

Samson, M.G.M., R.M. Vanderbeck, and N. Wood. 2018. Fixity and flux: A critique of competing approaches to researching contemporary Jewish identities. Social Compass 65: 97-113.

Saxe, Leonard, and Elizabeth Tighe. 2013. Estimating and understanding the Jewish population in the United States: A program of research. Contemporary Jewry 33 (1-2): 43-62.

Saxe, Leonard, Benjamin Phillips, Theodore Sasson, Shahar Hecht, Michelle Shain, Graham Wright, and Charles Kadushin. 2009. Generation Birthright Israel: The impact of an Israel experience on Jewish identity and choices. Waltham, MA: Cohen Center for Modern Jewish Studies, Brandeis University.

Schlosser, Lewis Z. 2003. Christian privilege: Breaking a sacred taboo. Journal of Multicultural Counseling and Development 31 (1): 44-51.

Schlosser, L.Z. 2006. Affirmative psychotherapy for American Jews. Educational Publishing Foundation 43: 424-435.

Sheskin, I. 2013. Use of local Jewish community study data for addressing national concerns. Contemporary Jewry. 33 (2013): 83-101.

Sheskin, I. 2017 greater Indianapolis Jewish population study. Berman Jewish Databank (2017). Accessed on 23 November 2019. https://www.jewishdatabank.org/databank/search-results?search=indiana

Smith, Zachary B., and Ashley Young. 2018. Jewish identity and religious commitments in the American Midwest: Results of a limited study on interfaith upbringing. Journal of Religion \& Society Supplement 16: 202-228.

Smith, William L., and Pidi Zhang, 2018. Jewish identity in a deep southern city. Virginia Social Science Journal 52.

Tajfel, H., and J.C. Turner. 1986. The social identity theory of intergroup behavior, psychology of intergroup relations, 7-24. Chicago: Nelson-Hall.

Thompson, J.A. 2013. Jewish on their own terms: How intermarried couples are changing American Judaism. Rutgers University Press.

Turner, J. 1991. Social influence. Milton Keynes, Brooks-Cole, Monterey, California: Open University Press. Weissbach, L.S. 2008. Jewish life in small-town America: A history. Yale University Press.

Young, Iris M. 1990. Chapter 5. The scaling of bodies and the politics of identity. In Justice and the Politics of Difference, 122-155. Princeton: Princeton University Press.

Zemel, C., and J. Looking. 2015. Visual culture and modern diaspora. Indiana University Press.

Publisher's Note Springer Nature remains neutral with regard to jurisdictional claims in published maps and institutional affiliations.

Emma Cieslik is a graduate of Ball State University with a B.A. in public history and biology, with minors in anthropology and Spanish. She is the recipient of two undergraduate research fellowships. She researches historical and anthropological effects of religion and has conducted archival and ethnographic research on Jewish identity and experiences of antisemitism in East-Central Indiana. More recently, Cieslik has conducted ethnographic research related to religious identity and clothing among practicing Catholic women across the USA, focused in Muncie, Indiana. 
Robert Phillips is an associate professor of anthropology at Ball State. He lectures on ethnographic methods and the anthropology of religion. His early fieldwork was in South India, but most of his empirical research was conducted in Singapore, focusing on how interactions on the Internet affect national and sexual subjectivity. More recently, Phillips has been conducting research in Brooklyn, NY and Jerusalem, Israel, focusing on religious subjectivity among Orthodox Jewish men. He is the author of Virtual Activism: Sexuality, the Internet, and a Social Movement in Singapore, published by the University of Toronto Press in 2020. 